
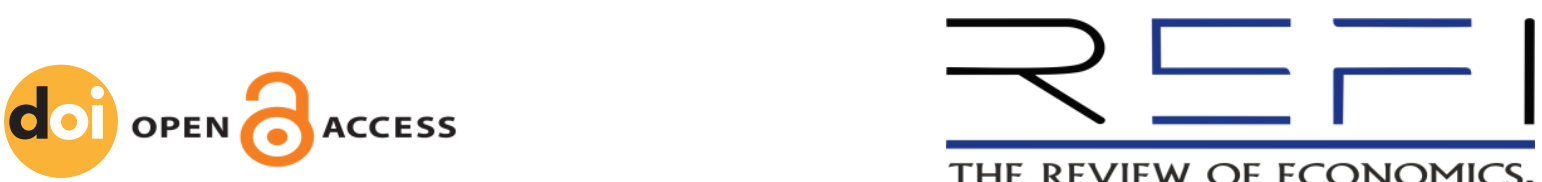

\title{
The Calendar Anomalies on Warsaw Stock Exchange in $2015-2020$
}

\author{
By MATEUSZ MYŚLIWIEC*
}

\begin{abstract}
The article is devoted to the subject of popular calendar anomalies. According to the theory of finance, if investors act rationally, the market can be considered efficient. In such a situation, achieving an above-average rate of return is impossible, as securities reflect all available information about them. However, on the basis of many studies and assumptions of behavioral economics, numerous exceptions to this rule have been discovered, which have been called market anomalies or stock anomalies. Such a deviation is the "January effect" and "January barometer" described in this work. The aim of the article is to investigate whether there is a deviation on the Warsaw Stock Exchange in 2015-2020 called the "January effect" and also whether the return rate in January can be a good prognosis for the rest of the year. In the results of the analysis, the occurrence of the title calendar effects in the studied sample was not unequivocally stated.
\end{abstract}

JEL Classification: E44, G14.

Suggested citation: Myśliwiec, M. (2020). The Calendar Anomalies on Warsaw Stock Exchange in 2015-2020. The Review of Economics, Finance and Investments, 1(1), 42-55.

\section{INTRODUCTION}

According to the market efficiency hypothesis, if investors act rationally, the market is efficient. In such a situation, achieving an above-average rate of return is impossible. However, already in the 1980 , evidence of deviations from this rule was discovered, which were called market anomalies or stock exchange anomalies (Czerwonka and Gorlewski 2008, p. 153). An anomaly is an exception, deviation, deviation from the norm or rule. Anomalies in financial markets are situations that allow investors who know them, assuming an appropriate strategy, to achieve an above-average rate of return (Peters 1997, p. 36). It follows from this definition that anomalies make it possible to partially predict the quotations of financial instruments and to obtain above-average income. In economics, there is also a more general definition of anomaly, according to which it is a technique or strategy that contradicts the assumptions of the market efficiency theory. Based on this finding, a market anomaly is a strategy that yields profits beyond the scope of the efficient markets hypothesis (Jones 1996, p. 282). Importantly, from this formula, we are not able to state how significant the rate of return must be achieved in order to be able to recognize the market as effective (Marianowska, Szerszyńska and Szymański 2016, p. 38). $\mathrm{G}$ Schwert claims that most of the anomalies turned out to be more illusory than real (Schwert, 2002). Researchers such as S. Shiller, A. Brav or J. Heaton attribute the existence of market anomalies to irrational investor behavior and errors conditioned by the presence of incomplete information (Brav and Heaton, 2002, pp. 575-606). E. Fama attributes this phenomenon to the nature of randomness and the burden of many errors (Fama, 1998, pp. 283-306).

Regarding the various aspects of the anomaly, we can highlight three subgroups of supporters of each approach. We can distinguish two extreme camps. The first two include those who completely deny

\footnotetext{
* Mateusz Myśliwiec; student at Podhale State College of Applied Sciences in Nowy Targ (Poland); email: mat.mys98@gmail.com.
} 
the occurrence of anomalies. The first camp rejects the significance of the phenomenon, e.g. by measurement errors. In turn, the second group, which includes the academics advocating the theory of market efficiency, exclude this thesis for rational reasons, as it is inconsistent with the assumptions of efficient markets. The last camp recognizes the significance and occurrence of stock market anomalies with respect to deviations from the market efficiency hypothesis. Importantly, this group does not necessarily have to reject these hypotheses, as it largely focuses on the gradual nature of the efficiency phenomenon (Lizińska, 2018, p. 270). On the basis of S. Buczek's analysis, anomalies can be divided into five categories: time anomalies, momentum strategies, market overreactions, anomalies related to the characteristics of companies and anomalies referring to the delayed reaction of investors to new information (Buczek, 2005, p. 51).

The main aim of the article is to investigate the "January effect" on the Warsaw Stock Exchange in 2015-2020, as well as whether the return rate in January could be a good predictor for the rest of the year.

\section{LITERATURE REVIEW}

\section{Capital market anomalies and negation of the market efficiency theory}

When carrying out an empirical analysis of market deviations, one of the most important and, at the same time, the most difficult things is to determine the time interval, i.e. the prediction of how long it will take to achieve above-average rates of return, in order to be able to systematize this phenomenon as a significant deviation from market rationality and call it an anomaly. B Szczepaniak and A. Klim raise an important question whether a one-off achievement of an above-average rate of return is adequate to undermine the theory of market efficiency and whether then we are dealing with an ineffective market. If we again recognize that the market is very efficient, can the occurrence of the dependence of rates of return in different time periods be considered only a prediction error (Szczepaniak and Klim, 2017, p. $32)$ ?

\section{The effect of the month of the year - 'January effect', 'December effect' and 'January barometer'}

Seasonal anomalies in literature have a very long history. The month-of-year effect, or the "January effect", is one of the most popular seasonal anomalies. Economists also point to other, no less important, seasonal deviations, which include the "January effect" as a barometer for the entire year, "turnof-the-month effects", anomalies related to holidays, "weekday effects", and even price effects referring to the phases of the moon or unlucky dates (Lizińska, 2018, p. 271). The "December effect" (also known as the Santa Claus rally), "Mark Twain effect" is also very popular "(According to this theory, share prices decrease in October) and" summer rally "(share prices increase in summer months) (Bogdański, 2017, p. 37).

According to P. Fiszeder and J. Kożuchowska, "calendar effects" are periodic fluctuations in the rates of return of financial instruments, during which the investment result is visibly higher or lower depending on the time of the day, day of the week and month of the year. Due to the large number of both theoretical and empirical studies, the most recognizable seasonal effect is the "effect of the month" (Fiszeder and Kożuchowska, 2013, p. 2). Research on the "effect of the month" showed high January rates of return on stocks. This phenomenon was first mentioned by the banker S. Wachtel in 1942, however, the topic was described in more detail only nearly 40 years later (Wachtel, 1942, pp. 184-193). Ubiquitous studies (by researchers such as S. Rozeff and W. Kinney or E. Dimson) have shown the significance of the thesis presented above - the rates of return in the first month of the year are on average higher than in the remaining months. Based on the observations of the first two researchers, the average rate of return on the NYSE in January was visibly higher than the average return on investment in the remaining months (Rozeff and Kinney, 1976, pp. 379-402). In 1983 M. Reinganum confirmed the significance of this phenomenon and outlined the fact that the "January effect" mainly concerned small 
capitalization companies, which suggests that this deviation is related to the "size effect of companies" (Reinganum, 1983, p. 89-104). More recent studies, carried out with the use of more innovative methods, indicate that the "January effect" is also visible in relation to large enterprises (Szyszka 2009, p.166).

The best known explanation for the 'January effect' theory is the divestiture of shares in a company for tax reasons. At the end of the year, investors are selling off stocks of companies that have fallen in price over the past twelve months in order to be able to deduct losses on their investments from their capital gains. The necessary condition for making this deduction is the actual loss, which is tantamount to closing a loss position, i.e. selling shares with a negative rate of return. Such a procedure is a determinant of the emergence of supply pressure. At the beginning of the next year, decision makers decide to buy back the stock, as it is undervalued due to the aforementioned supply pressure. Therefore, increased activity is taking place during the first five sessions of the new year. This hypothesis is confirmed, among others, by research by E. Dyl and H. Chen and V. Signal, which talks about increased demand for shares of companies, the quotations of which have fallen in the last year in January and December (Szyszka, 2003, p. 165).

M. Gultekin pointed to the presence of the "month effect" in 16 other countries (except the USA). Importantly, in these cases, such a visible correlation between the seasonality of returns and the size of the enterprise was not documented (Gultkein, 1983, pp. 469-481). It is worth noting that the January effect also occurred in countries where there is no tax on capital gains, e.g. in Japan, (Kiyoshi, 1985, pp. 243-260) and in countries where the tax year is not the same as the calendar year e.g. in the United Kingdom, (Reinganum and Shapiro, 1987, pp. 281-295). At first glance, these observations may seem contrary to the aforementioned sell-off hypothesis for tax reasons, but one should remember about the far-reaching process of globalization and strong connections between capital markets (Marianowska, Szerszyńska and Szymański, 2016, p. 40).

While the sale of shares for tax reasons seems rational, it is undoubtedly difficult to explain why investors, after selling and selling their shares, do not relocate their capital immediately, but wait until the beginning of January to open new positions in its first days. The answer to this question is strongly related to the psychology of investor behavior. Postponing investment decisions until the first sessions after the new year is associated with the phenomenon of the so-called mental accounting. In December, we summarize, analyze cash flow, bills, and do not dwell on new investments. The new year raises new expectations. We build investment strategies usually in isolation from the previous year. New year, new start. That is why, at the beginning of January, portfolios are created and capital is invested in shares. On the other hand, keeping losing positions until the end of the year is associated with loss aversion and the "disposition effect". Until the last moment, we believe that the trend will reverse and our predictions will come true. Excessive self-confidence makes us realize that we have made the right decision, we will avoid loss. We do not want to admit our mistake. The price at which we made the purchase is, in our opinion, "fair" value. We do not pay attention to fundamental changes in the company. We anchored ourselves around the purchase price. It is only when the end of the year is approaching and there are evident tax incentives that we admit to failure and recording a loss which, as a result of tax deduction, is less burdensome for us (Szyszka, 2009, pp. 168-169).

The behavior of institutional investors is also responsible for the "first month effect" of the year. To a large extent, the managerial remuneration depends on the achieved results on the accounts. Most managers are required to provide clients with annual reports, which must include, among other things, the composition of the portfolio. Managers, in order to increase their results, are obliged to reconstruct the portfolio at the end of the year - to get rid of the loss-making stocks. Then they will prove that they have stocks of reputable successful companies under their management. With the advent of the new year, they buy risky assets with an increased expected rate of return on a massive scale [Szczepaniak and Klim, 2017, p. 33].

The so-called January barometer. It is often called the "second January effect" or "other January effect" (Czerwonka and Gorlewski 2008, p. 175). This anomaly indicates whether the January effect may be a good forecast for the entire year on the market. In other words, the rate of return in January allows us to predict the rate of return at which the year will end. When January ends with a positive return, based on the "other January effect" hypothesis, the entire year will also end above zero. However, when 
the first month of the year ends in minus, the rate of return for the entire year will also be negative. Research by M. Cooper J. McConnell and A. Ovtchinikov showed that in the years 1940-2003 on the American market, when the first month ended with a positive rate of return, the average return on the remaining months in a given year was around $15 \%$ on the other hand, when January ended below zero, the average income rate did not exceed the level of 3\% (Cooper et al. 2006, pp. 315-341). However, despite concrete evidence of the rationality of the January barometer, other works on the subject appear to be in opposition. M. Bohl and C. Salm in their study proved that the "other January effect" is a random phenomenon. On the basis of the research results, they found that the "January barometer" disappeared completely after 1980 (Bohl and Salm, 2009, pp. 173-182).

The observation of the "January anomaly" was also not overlooked by Polish market analysts. The significance of this phenomenon on the Warsaw Stock Exchange was examined by, among others, M. Marianowska, E. Szerszyńska and M. Szymański. The results of the research of these three showed that on the Warsaw Stock Exchange one could observe the anomaly most widely described in this work, ie the "January effect". Quotations of the WIG20 index from 1992, i.e. almost from the beginning of the WSE SA operation until 2016, were characterized by the highest rate of return in January. On the other hand, research conducted on sWIG8o and mWIG40 companies did not show this relationship, however the results clearly indicate that the first four months were characterized by significantly higher rates of return than the remaining months. The "second effect of January" was visible, but the last years covering the research showed its significant weakening (Marianowska, Szerszyńska and Szymański, 2016, pp. 4247).

The methods of testing the presence of calendar effects in their assumptions should take into account the non-normality of the distribution of rates of return. Therefore, P. Fiszeder and J. Kożuchowska used the permutation test and the GARCH model to analyze the calendar effects on the WSE. The results of these studies for the WIG and WIG2O indexes show slight weekly fluctuations, the occurrence of the "turn of the month effect" and the lack of seasonal fluctuations. Importantly, higher rates of return were observed on Mondays and visibly lower rates on Wednesdays compared to other days of the week, but this was the case only for one of the methods, and only for WIG2O, and only at the significance level of o.1 (Fiszeder and Kożuchowska, 2013, pp. 2-11).

The term "Santa Claus Rally" dates back to the 1960s. It was first used by S. Wachtel in "Journal of the Business of the University of Chicago" (Wachtel, 1942, pp. 184-193). However, it was used primarily as a criticism of the theory of effective markets preached at that time. Various types of exceptions or anomalies were used by critics of E. Fam's hypothesis to refute and deny it. Mikolaj brings gifts in the form of above-average rates of return This phenomenon, as the name suggests, refers to the observed recurring pattern of an increase in share prices at the end of the year, in the pre-Christmas period (Szczepaniak and Klim, 2017, p. 35).

The anomaly directed at achieving above-standard rates of return in the year-ending period was first recorded in 1835 in Great Britain. In the United States, around 1870, after the introduction of the Christmas holiday, above-average returns on stocks were recorded during the last five trading sessions and the first two trading days of the new year (Washer, Nippani and Johnson, 2016, pp. 817-829). The analysis carried out by B. Szczepaniak and A. Klim confirmed the significance of the effect of the Santa Claus Rally. The verification of this anomaly proved that December was by far the best investment month of the year as the average income rate was $4.15 \%$. In $2 / 3$ cases, from the beginning of the stock exchange in Poland in December, it was possible to cash in a profit. The chance of obtaining a positive rate of return in the last month in the years 1991-2015 was as much as $66.67 \%$, which was 6.67 percentage points more than the second month in the statement and by 26.67 percentage points more than in June, the last ranking period (Szczepaniak and Klim, 2017, pp. 35-36).

The cause of Saint Nicholas' anomaly is believed to include:

1. Behavior of managers managing investment funds. Such persons receive a bonus at the end of the year, which very often depends on their portfolio performance. Therefore, at the end of the year, institutional investors are looking for ways to "pump up" share prices, using companies that are not very liquid and the relative ease of controlling the share price.

2. Fewer traders taking short positions. The pre-holiday season is a time when a large proportion of people decide to go on a longer vacation, which means that many institutional investors will not trade. 
This may result in a smaller number of traders playing to downturns, while the algorithms of investment funds with a long position will remain.

3. Tax issues. At the end of the year, many investors are trying to take full advantage of the available limits under their investment programs. The influence of fresh capital acts on the increased demand in the market, which results in higher quotations.

4. The mood of the decision makers. The pre-Christmas climate has a very positive effect on investors. Better moods of individual units significantly affect the improvement of the stock market sentiment (Szczepaniak and Klim, 2017, p. 36).

\section{Other calendar effects}

When analyzing calendar effects, it is worth paying attention to the so-called day-to-week effect. It was shown that in the US market the average rates of return between Friday and Monday close of the trading session were visibly lower than the average rates of return for the remaining days. On the NYSE, the average rates of return on Mondays were significantly lower than the average returns for the remaining days (Fiszeder and Kożuchowska, 2013, p. 3). K. French discovered the repeatability of Monday's rates of return and found that the average rate of return on Monday was negative (French, 1980, pp. 5569). Also M. Smirlock and S. Starks, who in the years 1963-1968, after analyzing the hourly data of the Dow Jones Industrial Average, found that in the first hour of Monday's session the rates of return were negative on average, and on other days the rates of return from the first hour of the session was positive (Smirlock and Starks, 1985). This anomaly is known as the "Monday effect" or "weekend effect". The hypothesis explaining this phenomenon was discussed by A. Damodaran. According to the economist, lower Monday's rates of return are due to the fact that negative information is disclosed by listed companies most often on Friday afternoon. Investors attach less importance to the Friday news, even if the announcement took place during the course of a trade. It can be argued that investors looking for a weekend break pay much less attention to new information from companies. Therefore, it cannot be ruled out that the low rates of return on Monday are the result of a delayed reaction of individual investors to the negative information announced on Friday. The information announced on Saturday or Sunday cannot be discounted on an ongoing basis, as these are days without a trading session (Damodaran, 1989, pp. 607-623). The lack of a significant market reaction to the information released to the public on Friday is also visible in the work of M. Bagnoli, M. Clement and S. Watts (Bagnoli, Clement, and Watts, 2006). In some countries, the "Monday effect" starts the following day, ie we have a "Tuesday effect". According to J. Bildik, the "Monday effect" is visible on the Turkish market (Bildik, 2004), and on the basis of research by N. Kanaryan, K. Lyroundi and P. Patev in the Czech Republic and Romania (Patev, Lyroudi, and Kanaryan, 2003).

The "turn-of-the-month effect", i.e. an anomaly raised by American scientists (Lakonishok and Schmidt, 1988, pp. 403-425) and Polish scientists (Hensel and Ziemba, 1995), is based on the apparently higher average rates of return in the last days of the previous month and in the first days of the next month. This effect is most pronounced in the US stock market. The vast majority of studies included a period of four sessions. The determinant of this effect is primarily investing a part of the salary. A significant number of employees receive remuneration for their work at the turn of the month. After receiving cash, we are prone to increased demand, including the purchase of shares on the stock exchange (Fiszeder and Kożuchowska, 2013, p. 3).

On the American stock exchange, apart from the "January effect", the "May effect" and the "September effect" could be noticed. The former is characterized by lower rates of return in the analyzed month, while the latter is characterized by high rates compared to the remaining months. The reason is the fact that in May, before the holiday season, we close positions, again in September we influence increased demand through new investments (Zawadzki, Troska i Domańska, 2017, p. 9). R. Ariel's 1987 study, carried out on data from 1963 to 1981, initiated the reflection on the "week-in-month effect". Ariel divided the month into two even parts and noticed that the cumulative rate of return in the analyzed period of 19 years is higher for the first part and amounts to $2552 \%$, while for the second part it is about o\% (Ariel, 1987). It is also worth paying attention to the "holiday effect", which is emphasized by high 
positive rates of return on days preceding the trading sessions taking place immediately before the holiday (public holiday) and relatively low rates of income during the first trading sessions after these days (holidays) (Ślepaczuk, 2006 , pp. 1-10). In the literature on the subject, the aforementioned "Mark Twain effect", according to which the shares should be held for most of the year, except for October, and the "summer rally effect", on the basis of which the vacation period is the best time to hold shares, is much less common (Fiszeder and Kożuchowska, 2013, p. 2).

\section{DATA AND RESEARCH METHODOLOGY}

The research was conducted on the basis of data from the Warsaw Stock Exchange. The following indices were analyzed: WIG and WIG20 in 2015-2020. The data for the calculations were taken from the website stooq.pl. It is worth paying attention to the fact that 2020 was an exceptional period from the point of view of stock exchange quotations, therefore, when analyzing the rates of return from this period, it should be borne in mind that they were abnormal, unnatural.

The analysis will consist of two interconnecting parts, casting an appropriate view on the given empirical results and providing more precise conclusions. At the beginning, attention will focus on the search for the "effect of the month", narrowing the main results to the "January effect" or December effect on the WSE, while the second part will relate to the analysis of the "January barometer". The analysis will calculate the arithmetic mean of the rate of return for each month. Importantly, when calculating the rates of return for the WIG index, the quotations of both its shares and the income from dividends and subscription rights will be taken into account, which results from the fact that this benchmark is a profitable index. The account for the WIG2O index will only take into account the prices of shares included in it, without taking into account the dividends due, as it is a price index. Transaction costs were not included in the analyzes.

\section{EMPIRICAL ANALYSIS - RESULTS AND DISCUSSION}

Table 1 shows that the study of the rates of return in 2015-2020 for the WIG2O stock exchange index showed that the "January effect" in its "pure" form does not occur. April was the month with the highest rate of return in the analyzed period. The podium was closed by two adjacent winter months, December and November. So we can see that January was not even in the top three. It is worth noting, however, the presence of that month in positive results, as the ranking period ended with a rate of return of $1.14 \%$. This result turned out to be better than 8 out of 12 analyzed months, which gives a result more attractive than $66.67 \%$ of the analyzed periods. The good results for April and November are largely the result of the covid-19 epidemic, and more specifically the "post-fall" stock market rebound. This is especially visible in the fall month, where in 2020 the rate of return was as high as $20.72 \%$. This result is by far the best achievement, far behind the rest of the stake. The average rate of return in April hovered around $3.79 \%$.

Following this line of thinking, the months where the results should be much more favorable, and whose rate of return suffered from an abnormal, unexpected phenomenon (read coronavirus) are the following periods: February, March and October. What is more important, in the period of the examined 6 years, January ended the quotations with the proverbial "plus". We could notice a drop in quotations in 2 years: 2016 and 2020, which means that the investment at the beginning of January and the sale of shares at the end of the month ended with a positive return with a probability of $66.67 \%$. In turn, the "December effect" was more visible than the "January effect". The average income rate was $2.40 \%$, second only to one month, April. In the experimental period, the rates of return for December were partially distributed: they were below the mark in 2015, 2018 and 2019, while in the remaining years they ended above zero. If, in the analyzed period, we only invested our capital in December, buying at the beginning of the first session in December and selling just before the close of the last session of the year, our investment would end up "in plus" in 50\% of cases. The same proportion can also be seen in the last column of Table 1 below, which proves that the average rate of return for the analyzed months is distributed 
in a half way, with a positive result in 50\%. This result consists of the negative rate of return from February, March, May, June, September and October. The lowest average rates of return are recorded in the months most marked by the coronavirus pandemic, i.e. February, March, September and October. The abnormal returns for 2020 of $-14.38 \%,-14.48 \%,-4.86 \%$ and $-11.49 \%$ respectively reduced the bottom line results for these periods. On the other hand, the months with the income rates closest to zero were August with a result of $0.37 \%$ and June with a result of $-0.37 \%$.

Table 1. Rates of return from the WIG20 index for each of the twelve months of the year in the analyzed period (\%)

\begin{tabular}{|c|c|c|c|c|c|c|c|}
\hline Year & $\mathbf{2 0 1 5}$ & $\mathbf{2 0 1 6}$ & $\mathbf{2 0 1 7}$ & $\mathbf{2 0 1 8}$ & $\mathbf{2 0 1 9}$ & $\mathbf{2 0 2 0}$ & Average \\
\hline January & 1,08 & $-4,24$ & 5,59 & 3,76 & 4,55 & $-3,92$ & $\mathbf{1}, \mathbf{1 4}$ \\
\hline February & 1,11 & 2,46 & 6,54 & $-7,42$ & $-2,01$ & $-14,38$ & $\mathbf{- 2 , 2 8}$ \\
\hline March & 1,22 & 9,52 & $-7,00$ & $-6,51$ & $-0,86$ & $-14,40$ & $\mathbf{- 3 , 0 2}$ \\
\hline April & 4,95 & $-5,06$ & 9,23 & 3,69 & 0,96 & 8,98 & 3,79 \\
\hline May & $-3,05$ & $-4,66$ & 4,03 & $-5,88$ & $-4,07$ & 4,49 & $\mathbf{- 1 , 5 2}$ \\
\hline June & $-4,92$ & $-3,18$ & 0,82 & $-1,0$ & 3,95 & 2,10 & $\mathbf{- 0 , 3 7}$ \\
\hline July & $-3,90$ & 0,52 & 3,23 & 7,80 & $-2,16$ & 0,50 & $\mathbf{1 , 0 0}$ \\
\hline August & $-2,86$ & 1,92 & 5,98 & 1,56 & $-6,24$ & 1,85 & $\mathbf{0 , 3 7}$ \\
\hline September & $-4,50$ & $-4,69$ & $-2,50$ & $-2,26$ & 1,78 & $-4,86$ & $\mathbf{- 2 , 8 4}$ \\
\hline October & $-0,31$ & 6,15 & 2,91 & $-5,83$ & 0,96 & $-11,49$ & $\mathbf{- 1 , 2 7}$ \\
\hline November & $-6,52$ & $-0,91$ & $-4,60$ & 6,47 & $-1,60$ & 20,72 & $\mathbf{2 , 2 6}$ \\
\hline December & $-3,46$ & 8,32 & 2,18 & $-0,63$ & $-0,41$ & 8,41 & $\mathbf{2 , 4 0}$ \\
\hline
\end{tabular}

Source: https://stooq.pl/q/d/?s=wig20.

In the case of the broadest index on the Polish stock exchange, we dealt with a similar situation, as clearly shown in Table 2. After all, January ended the period under review with an average rate of return of $1.60 \%$, which despite significantly exceeding the rate of return on this index compared to the preceding example, i.e. the WIG2O index, led to a situation in which January in the ranking period fell by one position, giving way to July. The price reductions for the first period of the year on a monthly basis occurred in the same time horizon, in 2016 and 2020. In these years, January was the month that closed in "red". The aforementioned drop to fourth position is a solid argument to challenge the thesis about the "January effect". April turned out to be the most favorable month for investors - the yield ceiling is $3.72 \%$. November had the second best result, with the result amounting to $2.43 \%$. On the other hand, the average rate of income in December was very close to the rate of return on the blue chip index, being $0.01 \%$ lower. The end of the year, however, had to give way to second place to November, which, with $2.43 \%$, was only 0.04 percentage point behind it. Also, this analysis could be divided into two sixmonth, equal periods, where one is characterized by a negative rate of return, while the other was its opposite. The lowest rates of return were observed in March, May, September and October, which were respectively: $-2.10 \%,-1.96 \%,-1.83 \%$ and $-1.66 \%$. The average rate in June and August oscillated close to zero, $-0.04 \%$ and $0.44 \%$. 
Table 2. Rates of return from the WIG index for each of the twelve months of the year in 2015-2020 (\%)

\begin{tabular}{|c|c|c|c|c|c|c|c|}
\hline Month Year & $\mathbf{2 0 1 5}$ & $\mathbf{2 0 1 6}$ & $\mathbf{2 0 1 7}$ & $\mathbf{2 0 1 8}$ & $\mathbf{2 0 1 9}$ & $\mathbf{2 0 2 0}$ & Average \\
\hline January & 1,31 & $-4,69$ & 6,72 & 3,61 & 4,64 & $-1,99$ & $\mathbb{1}, 60$ \\
\hline February & 2,31 & 2,57 & 5,55 & $-6,58$ & $-0,77$ & $-13,06$ & $\mathbf{- 1 , 6 6}$ \\
\hline March & 1,48 & 7,90 & $-0,67$ & $-5,39$ & $-0,39$ & $-15,53$ & $\mathbf{- 2 , 1 0}$ \\
\hline April & 4,41 & $-2,81$ & 6,45 & 2,66 & 0,80 & 10,79 & 3,72 \\
\hline May & $-1,67$ & $-3,77$ & $-2,52$ & $-4,42$ & $-3,72$ & 4,36 & $\mathbf{- 1 , 9 6}$ \\
\hline June & $-3,97$ & $-2,39$ & 1,54 & $-2,32$ & 3,93 & 3,00 & $-\mathbf{0 , 0 4}$ \\
\hline July & $-1,08$ & 3,18 & 2,59 & 7,17 & $-0,86$ & 1,81 & $\mathbf{2 , 1 4}$ \\
\hline August & $-2,79$ & 3,82 & 3,80 & 0,39 & $-4,91$ & 2,30 & $\mathbf{0 , 4 4}$ \\
\hline September & $-2,84$ & $-1,77$ & $-1,05$ & $-2,04$ & 1,02 & $-4,30$ & $\mathbf{- 1 , 8 3}$ \\
\hline October & 0,90 & 4,40 & 0,90 & $-6,21$ & 0,81 & $-10,75$ & $\mathbf{- 1 , 6 6}$ \\
\hline November & $-4,69$ & $-1,10$ & $-3,74$ & 5,23 & $-0,49$ & 19,37 & 2,43 \\
\hline December & $-3,02$ & 6,45 & 2,90 & $-0,88$ & 0,58 & 8,33 & 2,39 \\
\hline
\end{tabular}

Source: https://stooq.pl/q/d/?s=wig20.

As mentioned above and as we can see in Table 3, the WIG20 index quotations in the analyzed period were strongly correlated with the price of the widest stock exchange index. This is an extremely normal situation, resulting from the fact that the companies included in the blue chip index are significant companies, the liquidity is much higher than in the case of the sWIG80 index or the NewConnect market. Variations in the quotations of the aforementioned indices ranged from 0.01 in the average rate in December to 1.14 percentage points in July. Each month was characterized by the same nature of the rate of return, which means that if January ended at positive levels for the WIG2O index, then the average rate of return in January for the WIG index was "in plus".

Table 3. Summary of average monthly rates of return for the WIG and WIG20 indexes for 2015-2020 (\%)

\begin{tabular}{|c|c|c|}
\hline Month Stock index & WIG20 & WIG \\
\hline January & 1,14 & $-1,66$ \\
\hline February & $-2,28$ & $-2,10$ \\
\hline March & $-3,02$ & 3,72 \\
\hline April & 3,79 & $-1,96$ \\
\hline May & $-1,52$ & $-0,04$ \\
\hline June & $-0,37$ & 2,14 \\
\hline July & 1,00 & 0,44 \\
\hline August & 0,37 & $-1,83$ \\
\hline September & $-2,84$ & $-1,66$ \\
\hline October & $-1,27$ & 2,43 \\
\hline November & 2,26 & 2,39 \\
\hline December & 2,40 & \\
\hline
\end{tabular}

Source: https://stooq.pl/q/d/?s=wig20. 
The above analyzes clearly indicate that we cannot speak of the "January effect" on the WSE in 2015-2020. However, as shown in the table below, the January average rate of return on the WIG2O index in the analyzed period was higher than the cumulative rate for the remaining months. Only in 2016 and 2020, the return in the first month was lower and amounted to: $-4.89 \%$ against $1.50 \%$ and $1.99 \%$ compared to $0.57 \%$ for the remaining months. The January rate of return in 2015, 2017, 2018, 2019 was more attractive by 3.1, 7.48, 4.64, and 5.43 percentage points, respectively. After all, the final result at the level of $1.14 \%$ cannot be attributed to the above-average, it is undoubtedly more attractive than the loss of around $0.13 \%$.

Table 4. Average rates of return from January compared to other months in 2015-2020 for the WIG20 index (\%)

\begin{tabular}{|c|c|c|c|c|c|c|c|}
\hline Month Year & 2015 & 2016 & 2017 & 2018 & 2019 & 2020 & Average \\
\hline January & 1,08 & $-4,24$ & 5,59 & 3,76 & 4,55 & $-3,92$ & 1,14 \\
\hline Other months & $-2,02$ & 0,94 & 1,89 & $-0,91$ & $-0,88$ & 0,17 & $\mathbf{- 0 , 1 3}$ \\
\hline
\end{tabular}

Source: https://stooq.pl/q/d/?s=wig20.

A similar situation took place with regard to the widest Polish stock exchange index, which is illustrated in Table 5. The average rate of income was clearly higher for January. The periods with worse results than the remaining months were the same years, i.e. 2016 and 2020, in which the average rate of return in the first month of the year was lower by 5.15 percentage points and 4.09 percentage points, respectively, which means two significant differences, showing the apparent weakness of the month in question. However, as a whole, investing in January may have resulted in higher, abnormal returns. The final result was higher by 1.43 percentage points, which can be considered a positive result.

Table 5. Average rates of return from January compared to other months in 2015-2020 for the WIG index (\%)

\begin{tabular}{|c|c|c|c|c|c|c|c|}
\hline Month Year & 2015 & 2016 & 2017 & 2018 & 2019 & 2020 & Average \\
\cline { 1 - 7 } January & 1,31 & $-4,69$ & 6,72 & 3,61 & 4,64 & $-1,99$ & 1,60 \\
\hline Other months & $-1,00$ & 1,50 & 1,43 & $-1,13$ & $-0,36$ & 0,57 & 0,17 \\
\hline
\end{tabular}

Source: https://stooq.pl/q/d/?s=wig20.

In the comparative analysis of the last month of the year with the remaining months, the results of which are presented in Table 6, we can notice that the average annual rate of return for WIG20 in December was definitely more attractive. The return of $2.40 \%$ compared to the $0.25 \%$ loss may be impressive as it is a difference of 2.65 percentage points. Such a good result was mainly influenced by two years: 2016 and 2020. The December WIG20 index in these years was able to grow by over 8\%, which was undoubtedly a great investment result. It is also worth noting that the rate of return for the group of eleven months was negative, which, given the income in excess of $2 \%$ in December, illustrates the "strength" of the month in question even more.

Table 6. Average rates of return from December compared to other months in 2015-2020 for the WIG 20 index (\%)

\begin{tabular}{|c|c|c|c|c|c|c|c|}
\hline Month Year & 2015 & 2016 & 2017 & 2018 & 2019 & 2020 & Average \\
\hline December & $-3,46$ & 8,32 & 2,18 & $-0,63$ & $-0,41$ & 8,41 & 2,40 \\
\hline Other months & $-1,61$ & $-0,20$ & 2,20 & $-0,51$ & $-0,43$ & $-0,95$ & $-\mathbf{0 , 2 5}$ \\
\hline
\end{tabular}

Source: https://stooq.pl/q/d/?s=wig20. 
For the WIG index, December also turned out to be an attractive month from the point of view of the rate of return. Similarly, it was most clearly visible in 2016 and 2020. It was in these years that the average rate of return was above 8.52 and 9.36 percentage points, respectively. This situation is illustrated by the following, i.e. tabular consolidation, i.e. Table 7 .

Table 7. Average rates of return from December compared to other months in 2015-2020 for the WIG index (\%)

\begin{tabular}{|c|c|c|c|c|c|c|c|}
\hline Month Year & 2015 & 2016 & 2017 & 2018 & 2019 & 2020 & Average \\
\hline December & $-3,02$ & 6,45 & 2,90 & $-0,88$ & 0,58 & 8,33 & 2,39 \\
\hline Other months & $-0,60$ & 0,49 & 1,78 & $-0,72$ & 0,01 & $-0,36$ & 0,10 \\
\hline
\end{tabular}

Source: https://stooq.pl/q/d/?s=wig20.

The second part of the study referred to the possibility of predicting the nature of the annual rate of return based on the January rate. The analysis was also carried out for the WIG and WIG2O indexes, using the same parameters. The validity of the following thesis was checked: if the rate of return for the first month of the year was positive, the rate of return for the entire year will also be above zero, and conversely, a negative return in January will have a negative effect on the result for the entire year. If this thesis is positively verified, January will be considered a good prognosis and the validity of the "January barometer" will be confirmed.

The table below shows that in the case of the WIG20 index, there were two years for which the January barometer worked fruitfully. In 2017, the first month was characterized by an income rate of $5.59 \%$, while the entire year ended with a result of $26.35 \%$. In turn, in 2020, the second part of the thesis was confirmed - the negative return in January was a forecast for the negative result of blue chip quotations throughout the year. The January barometer was confirmed in only $33.34 \%$ of the cases.

Table 8. The January barometer for the WIG20 index in 2015-2020 (\%)

\begin{tabular}{|c|c|c|c|}
\hline Year & January & All year & January barometer \\
\hline $\mathbf{2 0 1 5}$ & 1,08 & $-19,27$ & No \\
\hline $\mathbf{2 0 1 6}$ & $-4,24$ & 4,70 & No \\
\hline 2017 & 5,59 & 26,35 & Yes \\
\hline 2018 & 3,76 & $-7,50$ & No \\
\hline 2019 & 4,55 & $-5,56$ & No \\
\hline 2020 & $-3,92$ & $-7,73$ & Yes \\
\hline
\end{tabular}

Source: https://stooq.pl/q/d/?s=wig20.

The results of the research for the WIG index indicated a 50\% effectiveness of the second January effect. In 2017 and 2019, the positive rate of return in January correctly forecasted a positive rate for the entire year. The year 2020 confirmed its legitimacy with the negative rate of return in January and at the end of this year. The rates of return are shown in Table 9.

In addition, the occurrence of the "January barometer" has been examined since the beginning of the Stock Exchange, ie from 1991. However, the first year to be taken into account is 1992, as it is the inaugural year of January trading. Table 10 shows that January was a good prognosis for 18 out of 30 analyzed cases. In $60 \%$ of the cases, the rate of return for the entire year followed the same direction as the rate of return for January. The barometer did not work $40 \%$ of the time. 
Table 9. The January barometer for the WIG index in 2015-2020 (\%)

\begin{tabular}{|c|c|c|c|}
\hline Year & January & All year & January barometer \\
\hline $\mathbf{2 0 1 5}$ & 1,31 & $-9,62$ & No \\
\hline $\mathbf{2 0 1 6}$ & $-4,69$ & 11,38 & No \\
\hline $\mathbf{2 0 1 7}$ & 6,72 & 23,17 & Yes \\
\hline $\mathbf{2 0 1 8}$ & 3,61 & $-9,50$ & Yes \\
\hline 2019 & 4,64 & 0,25 & Yes \\
\hline
\end{tabular}

Source: https://stooq.pl/q/d/?s=wig20.

Table 10. The January barometer for the WIG index in 1992-2020 (\%)

\begin{tabular}{|c|c|c|c|}
\hline Year & January & All year & January barometer \\
\hline 1992 & 1,99 & 13,22 & Yes \\
\hline 1993 & 0,95 & 1095,37 & Yes \\
\hline 1994 & 35,71 & $-39,92$ & No \\
\hline 1995 & $-17,66$ & 1,51 & No \\
\hline 1996 & 37,27 & 89,07 & Yes \\
\hline 1997 & $12,2 \%$ & 2,27 & Yes \\
\hline 1998 & $-0,45$ & $-12,77$ & Yes \\
\hline 1999 & 13,89 & 41,33 & Yes \\
\hline 2000 & 7,27 & $-1,31$ & No \\
\hline 2001 & $-1,37$ & $-21,99$ & Yes \\
\hline 2002 & 15,38 & 3,19 & Yes \\
\hline 2003 & $-3,63$ & 44,92 & No \\
\hline 2004 & 5,41 & 27,94 & Yes \\
\hline 2005 & $-2,41$ & 33,66 & No \\
\hline 2006 & 6,33 & 41,60 & Yes \\
\hline 2007 & 8,22 & 10,39 & Yes \\
\hline 2008 & $-14,20$ & $-51,07$ & Yes \\
\hline 2009 & $-9,34$ & 46,85 & No \\
\hline 2010 & 0,18 & 18,77 & Yes \\
\hline 2011 & $-0,70$ & $-20,83$ & Yes \\
\hline 2012 & 8,86 & 26,24 & Yes \\
\hline 2013 & $-1,31$ & 8,06 & No \\
\hline 2014 & $-0,88$ & 0,26 & No \\
\hline 2015 & 1,33 & $-9,62$ & No \\
\hline 2016 & $-4,69$ & 4,26 & No \\
\hline 2017 & 6,72 & 23,17 & Yes \\
\hline
\end{tabular}




\begin{tabular}{|c|c|c|c|}
\hline 2018 & 3,61 & $-9,50$ & No \\
\hline 2019 & 4,64 & 0,25 & Yes \\
\hline 2020 & $-1,99$ & $-1,40$ & Yes \\
\hline
\end{tabular}

Source: https://stooq.pl/q/d/?s=wig20.

The summary of the results of the "January barometer" can be seen in Table 11. According to previous analyzes, the "January barometer" was a useful analytical tool in $60 \%$ of cases. Thus, this phenomenon can be largely attributed to a significant degree of randomness.

Table 11. Summary of the results of the January barometer for the WIG index in numbers and percentages

\begin{tabular}{|c|c|c|}
\hline January barometer & Number of results & Results (in \%) \\
\hline Yes & 18 & 60 \\
\hline No & 12 & 40 \\
\hline Total & 30 & 100 \\
\hline
\end{tabular}

Source: https://stooq.pl/q/d/?s=wig20.

\section{CONCLUDing REMARKS}

The discussion on the occurrence of calendar effects has aroused the interest of analysts and economists for years. In addition to the theoretical aspects, we also see empirical research trying to explain the anomalies. In the light of the research carried out, it can be indicated that there is no "January effect" or December effect in its pure form. For the index of 20 largest companies from the WSE, ie WIG20, the results showed that April was the month with the highest average rate of return. The broadest index, including all entities, ie WIG, showed the same relationship. This evidence distances the thesis at first glance. And it is impossible to disagree with this at all. However, it is worth noting that both January and December were characterized by positive rates of return. The presence of these two months in the top four should also be emphasized. On the other hand, the analysis of the "January barometer" revealed the randomness of the occurrence of this phenomenon in the analyzed period. A wider examination of this anomaly proved that in the initial stages of the stock exchange's development, the "second month effect" was visible, but over time the weakening of the barometer became stronger, as evidently shown by the analysis in the title years, i.e. 2015-2020.

The entirety of the analyzed research may create a certain dissonance, because on the one hand the effect of the month was not confirmed, while analyzing more deeply, the factors that could approve this thesis were visible. It should be noted that the analyzed period was relatively short, interspersed with abnormal phenomena that significantly distorted the final picture. In such an environment, inferring far-reaching results should be careful, supported by specific data containing results covering the largest possible time span. However, it is worth bearing in mind the strong connection of the calendar rhythm with many areas of everyday life, from those at the bottom of Maslow's needs to those at its top. At first glance, the discovered anomalies are a visible contradiction to the theory of market efficiency. This statement does not necessarily agree with E. Fama, who gave reasons why the anomalies described in this article do not necessarily contradict this hypothesis. As the basis for this thesis, he advances the following points:

1. Inability to obtain an above-average rate of return using investment strategies based on market anomalies (after taking into account transaction costs).

2. High apparent appearance of these deviations, which was confirmed by the disappearance of when analyzing other markets or other periods.

3. The problem of the joint hypothesis. 
4. Occurrence of anomalies as a result of sample bias, caused, among others, by the rejection of companies withdrawn from stock exchanges during the period study (Fama 1988, pp. 283-306).

E. Fama and K. French tried to explain the occurrence of anomalies using multivariate models. However, they managed to explain only the negative, long-term autocorrelations of returns on stocks (Fama and French, 1996, pp. 131-155). Other models assuming the rationality of the investor were not able to explain the existence of the anomaly.

\section{REFERENCES}

Ariel, R.A., (1987). A Monthly Effect in Stock Returns. Journal of Financial Economics, 18(1).

Bagnoli, M., Clement, M., Watts, S., (2006). Around-the-Clock Media Coverage and the Timing of Earning Announcements. Working Paper, University of Texas at Austin.

Bildik, R., (2004). Are Calendar Anomalies Still Alive?: Evidence from Istanbul Stock Exchange. Available at SSRN: https://ssrn.com/abstract=598904 or http://dx.doi.org/10.2139/ssrn.598904.

Bogdański, M., (2017). Występowanie efektów kalendarzowych na Giełdzie Papierów Wartościowych. Journal of Capital Market and Behavioral Finance, 2(6), 35-46.

Bohl, M.T., Salm C.A., (2009). The Other January Effect: international evidence. 173-182, https://doi.org/10.1080/13518470903037953.

Buczek, S., (2005). Efektywność informacyjna rynków akcji. Warszawa: Szkoła Główna Handlowa Oficyna Wydawnicza.

Brav, A., Heaton, J.B., (2002). Competing Theories of Financial Anomalies. Review of Financial Studies, 2(15), 575-606.

Cooper, M., McConnell, J., Ovtchinikov A., (2006). The other January effect. Journal of Financial Economics, 82.

Czerwonka, M., Gorlewski, B., (2008). Finanse behawioralne. Warszawa: Wydawnictwo Szkoła Główna Handlowa w Warszawie.

Damodaran, A., (1989). The Weekend Effect in Information Releases: A Study of Earnings and Dividend Announcements. The Review of Financial Studies. NC: Oxford Univ. Press, 2(4), 607-623.

Fama, E.F., (1998). Market Efficiency, Long-Term Returns, and behavioral Finance. Journal of Financial Economics, 49(3), 283-306.

Fama, E.F., French, K.R., (1966). Multifactor Explanations of Asset Pricing Anomalies. https://doi.org/10.1111/j.15406261.1996.tb05202.x.

Fiszeder, P., Kożuchowska, J., (2013). Testowanie występowania wybranych anomalii kalendarzowych na GPW w Warszawie. Prace Nankowe Uniwersytetu Ekonomicznego w Katowicach - Zastosowanie metod ilościonych w zarzadzaniu rysylkiem w driatalności inwestycyjnej, 217-229.

French, K.R., (1980). Stock Returns and Weekend Effect. Journal of Financial Economics, 8.

Gultkein, M., (1983). Stock Market Seasonality: International Evidence. Journal Of Finance And Economics, 12(4).

Hensel, C.R., Ziemba, W.T., (1995). The January Barometer. Journal of Investing, 2(4), 67-70.

Jones, C., (1996). Investments. Analysis and Management. Nowy Jork: Wydawnictwo John Willey \& Sons.

Lakonishok, J., Smidt, S., (1988). Are Seasonal Anomalies Real? A Ninety - Year Perspective. Review of Financial Studies, 1(4), 403425.

Lizińska, J., (2018). Anomalie rynkowe na polskim rynku kapitałowym w ujęciu empirycznym. Finanse, Rynki Finansowe, Ubeappieczenia - Mierzenie i ocena wyników przedsiebiorstw, 92(2), 269-279. https://doi.org/10.18276/frfu.2018.92-23.

Marianowska, M., Szerszyńska, E., Szymański, M., (2016). Anomalie sezonowe na rynkach kapitałowych: efekt stycznia i barometr stycznia na Giełdzie Papierów Wartościowych w Warszawie. Journal of Capital Market and Behavioral Finance, 3(1), 35-48.

Patev, S., Lyroudi, A., Kanaryan, N., (2003). The Day of the Week Effect in the Central European Transition Stock Markets, Tsenov Academy of Economics Finance and Credit, Working Paper No. 03-06.

Peters, E., (1997). Teoria chaosu a rynki kapitałowe. Warszawa: Wydawnictwo WIG-Press.

Reinganum, M.R., (1983). The Anomalous Stock Market Behavior of Small Firms in January: Empirical Tests for Tax-Loss Selling Effects. Journal of Financial Economics, 12, 89-104. http://dx.doi.org/10.1016/0304-405X(83)90029-6.

Rozeff, M. S., Kinney, W. Jr., (1976). Capital market seasonality: The case of stock returns. Journal of Financial Economics, Elsevier, 3(4), 379-402.

Schwert, G.W., (2002). Anomalies and Market Efficiency. Simon School of Business Working Paper, 02-13. http://ssrn.com/abstract $=338080$ (data dostępu 15.05. 2021).

Smirlock, M., Starks, L., (1986). Day-of-the-Week and Intraday Effects in Stock Returns. Journal of Financial Economics, 17.

Szczepaniak, B., Klim, A., (2017). Święty Mikołaj rozpoczyna rajd... . Journal of Capital Market and Behavioral Finance, 5(1), 29-39.

Szyszka, A. (2009). Finanse Behawioralne, Poznań: Wydawnictwo Uniwersytetu Ekonomicznego w Poznaniu.

Szyszka, A., (2003). Efektywność Giełdy Papierów Wartościowych w Warszawie na tle rynków dojrzałych. Poznań: Wydawnictwo Akademii Ekonomicznej w Poznaniu.

Wachtel, S., (1942). Certain Observations on Seasonal Movements in Stock Prices. Journal of Business, 15(2), 184-193.

Washer, K., Nippani, S., Johnson, R., (2016). Santa Claus Rally and firm size. Managerial Finance, 42, $817-829$. https://doi.org/10.1108/MF-10-2015-0280 (data dostępu 18.05.2021).

Zawadzki, A., Troska, D., Domańska, M., (2017). Anomalie kalendarzowe na giełdzie papierów wartościowych w Warszawie. Journal of Capital Market and Behavioral Finance, 5(1), 7-15. 
CONFLICT OF INTEREST:

The authors declare that they have no material or financial interests associated with the research presented in this article. The authors declare that the study was conducted in the absence of any commercial or financial relationship giving rise to a conflict of interest.

\section{COPYRIGHT AND LICENSE:}

\section{(c) (1) $\Theta$}

This article is published under the terms of the Creative Commons

Attribution - NoDerivs (CC BY-ND 4.0) License

http://creativecommons.org/licenses/by-nd/4.o/

Published by Podhale State College of Applied Sciences - Nowy Targ, Poland 